\title{
DNA microarray of global transcription factor mutant reveals membrane-related proteins involved in $n$-butanol tolerance in Escherichia coli
}

\author{
Hai-Ming Si, Fa Zhang, An-Ning Wu, Rui-Zhi Han, Guo-Chao Xu and Ye Ni ${ }^{*}$
}

\begin{abstract}
Background: Escherichia coli has been explored as a platform host strain for biofuels production such as butanol. However, the severe toxicity of butanol is considered to be one major limitation for butanol production from E. coli. The goal of this study is therefore to construct butanol-tolerant E. coli strains and clarify the tolerance mechanisms.

Results: A recombinant E. coli strain harboring $\sigma^{70}$ mutation capable of tolerating $2 \%(\mathrm{v} / \mathrm{v}$ ) butanol was isolated by the global transcription machinery engineering (gTME) approach. DNA microarrays were employed to assess the transcriptome profile of butanol-tolerant strain B8. Compared with the wild-type strain, 329 differentially expressed genes (197 up-regulated and 132 down-regulated) $(p<0.05 ; F C \geq 2)$ were identified. These genes are involved in carbohydrate metabolism, energy metabolism, two-component signal transduction system, oxidative stress response, lipid and cell envelope biogenesis and efflux pump.

Conclusions: Several membrane-related proteins were proved to be involved in butanol tolerance of E. coli. Two down-regulated genes, yibT and yghW, were identified to be capable of affecting butanol tolerance by regulating membrane fatty acid composition. Another down-regulated gene ybjC encodes a predicted inner membrane protein. In addition, a number of up-regulated genes, such as $g c l$ and $g / c F$, contribute to supplement metabolic intermediates for glyoxylate and TCA cycles to enhance energy supply. Our results could serve as a practical strategy for the construction of platform E. coli strains as biofuel producer.
\end{abstract}

Keywords: Butanol tolerance, DNA microarrays, Membrane-related proteins, Global transcription machinery engineering, Escherichia coli

\section{Background}

Concerns on global energy crisis and environmental problems have prompted the development of renewable biofuels as potential alternatives for replacing traditional fossil fuels. Among biofuels, butanol has attracted much attention due to its higher energy density, miscibility with gasoline and lower corrosivity [1]. Escherichia coli, as an important platform microorganism, has been widely engineered as an alternative host for the production of

\footnotetext{
*Correspondence: yni@jiangnan.edu.cn

The Key Laboratory of Industrial Biotechnology, Ministry of Education, School of Biotechnology, Jiangnan University, Wuxi 214122, Jiangsu, China
}

various biofuels due to its advantages of fast growth and easy genetic manipulation [2, 3]. However, most biofuels are toxic to $E$. coli, which barely tolerate organic solvents with $\log P$ values lower than 3.4-3.8 [4]. For example, cell growth of $E$. coli is completely inhibited in the presence essary to improve the butanol tolerance of E. coli.

Most industrial biofuel-producing strains were obtained through solvent stress adaptation, genetic and metabolic engineering and traditional mutagenesis [6-9]. However, long-term adaptive evolution and traditional 
mutagenesis are often time-consuming. Significantly improved microbial tolerance requires a complex and multigenic phenotype. With recent development of direct mapping between the transcriptome and phenotype, strain improvement efforts have been focused on the manipulation of transcription factors. Global transcription machinery engineering (gTME) emerged as a promising strategy and has been widely used to evolve the desired phenotypes in recent years [10,11]. Several transcription factors, including sigma factor, CRP, Spt15, $\mathrm{H}-\mathrm{NS}$ and Hha, have been successfully engineered to improve organic solvent tolerance of various microbial strains [12-15]. $\sigma^{70}$ is a subunit of RNA polymerase encoded by rpoD, which regulates over 1000 genes in $E$. coli. Studies showed that $\sigma^{70}$ mutations could alter the promoter preferences of RNA polymerase and therefore affect transcriptome at a global level [16-18]. Our group previously isolated an $E$. coli harboring $\sigma^{70}$ mutant C9, which could grow in the presence of $69 \%(\mathrm{v} / \mathrm{v})$ of cyclohexane [19].

Many solvent tolerance-related genes and their mechanisms have been reported in E. coli strains. MarA (encoded by marA) was confirmed to be a transcription factor capable of inducing the expression of mar-sox regulon genes [20, 21]. Disruption of proV and marR genes could increase the $n$-hexane tolerance of $E$. coli cells, possibly due to their function in regulation of osmotic pressure [22]. Rutherford and coworkers reported that $\mathrm{n}$-butanol stress response genes are also involved in other stress responses, such as oxidative stress $(\operatorname{sod} A, \operatorname{sod} C$ and $y q h D)$, heat shock and cell envelope stress (rpoE, $\operatorname{clpB}$, $h t p G, c p x R$ and $c p x P$ ) [23]. In our previous study, E. coli strain overexpressing $m m s B$ (encoding 3-hydroxyisobutyrate dehydrogenase) exhibited high solvent tolerance by generating more energy to pump out intracellular organic solvent [24]. These studies demonstrate the complexity and diversity of solvent tolerance mechanisms in E. coli.

It has been reported that $E$. coli strain capable of growing in the presence of $1.2 \%(\mathrm{v} / \mathrm{v})$ butanol was obtained by engineering the global transcription factor cyclic AMP receptor protein [13]. Recently, n-butanol tolerance of $E$. coli was expanded to $2 \%(\mathrm{v} / \mathrm{v})$ by engineering an artificial transcription factor combining with controlling membrane-related functions [25]. In this work, we aimed to improve the butanol tolerance of $E$. coli by a feasible and efficient approach gTME and understand the mechanism between rpoD mutagenesis and the evolved phenotype. An $E$. coli strain carrying $\sigma^{70}$ mutant capable of tolerating as high as $2 \%(\mathrm{v} / \mathrm{v})$ butanol was isolated, which is close to the highest butanol tolerance level of E. coli reported so far. DNA microarrays were employed to identify critical genes related to the n-butanol tolerance based on the transcriptome profile of mutant B8 compared with its wild type (WT). Several membrane-related genes (such as $y i b T, y g h W$ and $y b j C$ ) were recognized to affect membrane fatty acid composition or function as a membrane protein. Other genes (such as $g c l$ and $g l c F$ ) involved in enhancing metabolic intermediates levels for glyoxylate and TCA cycles were also identified.

\section{Results and discussion}

\section{Isolation of $\sigma^{70}$ mutants}

To obtain $\sigma^{70}$ mutants with high n-butanol tolerance, random mutagenesis was performed to construct a rpoD mutant library of around $10^{6}$. In the first round of screening, 483 mutants were selected from the mutagenesis library on agar plate containing $0.5 \%(\mathrm{v} / \mathrm{v})$ butanol. They were further inoculated into 24 -well plate under butanol pressure. Among them, ten mutants with $\mathrm{OD}_{660}$ of 1.3-2.0 were selected due to their advantageous growth under $0.5 \%(\mathrm{v} / \mathrm{v})$ butanol than other mutants $\left(\mathrm{OD}_{660}<1\right)$ (Fig. 1a). Then these mutants were cultured in medium containing 0.5-1.5\% (v/v) n-butanol $(0.1 \%$ gradient increasing). One mutant exhibited the highest tolerance $\left(0.76 \mathrm{OD}_{660}\right)$ at $1.2 \%(\mathrm{v} / \mathrm{v}) \mathrm{n}$-butanol and was designated as D3, which was confirmed with two amino acid substitutions (I41L, P97Q).

To further improve the butanol tolerance, the second round of random mutagenesis was performed to construct a variant library using D3 as a template. In the second round of screening, eight mutants exhibited higher butanol tolerance $\left(\mathrm{OD}_{660}>2.0\right)$ than others (Fig. 1b). In further screening under $0.5-1.5 \%(\mathrm{v} / \mathrm{v})$ butanol $(0.1 \%$ gradient increasing), one mutant B8 with three substitutions (I41L, E57D, P97Q) exhibited excellent growth in the presence of $1.2 \%(\mathrm{v} / \mathrm{v})$ butanol, reaching $1.432 \mathrm{OD}_{660}$ compared with 0.778 of D3 and 0.247 of WT (Additional file 1: Figure S1). Then, mutants B8, D3 and WT were further cultured under higher n-butanol concentration (1.2-2.2 \%) to assess their maximum butanol tolerance (Fig. 2a). The cell growth of WT was completely inhibited when butanol reached over $1.2 \%(\mathrm{v} / \mathrm{v})$, and mutant D3 could hardly grow in the presence of $1.6 \%(\mathrm{v} / \mathrm{v})$ butanol. Nevertheless, for mutant $\mathrm{B} 8, \mathrm{OD}_{660}$ reached 0.372 after $8 \mathrm{~h}$ incubation with $2.0 \%(\mathrm{v} / \mathrm{v})$ butanol, suggesting a much higher butanol tolerance than D3 and WT, while no cell growth was observed for B8 at over $2.0 \%(\mathrm{v} / \mathrm{v})$ n-butanol. Finally, B8 was selected as the best candidate for further study.

\section{Characterization of butanol-tolerant mutants Solvent shock experiments}

To further characterize the tolerance of B8, solvent shock experiments were performed in medium containing higher concentration of n-butanol. As shown in Fig. 2b, the growth of B8 and WT has no significant difference 

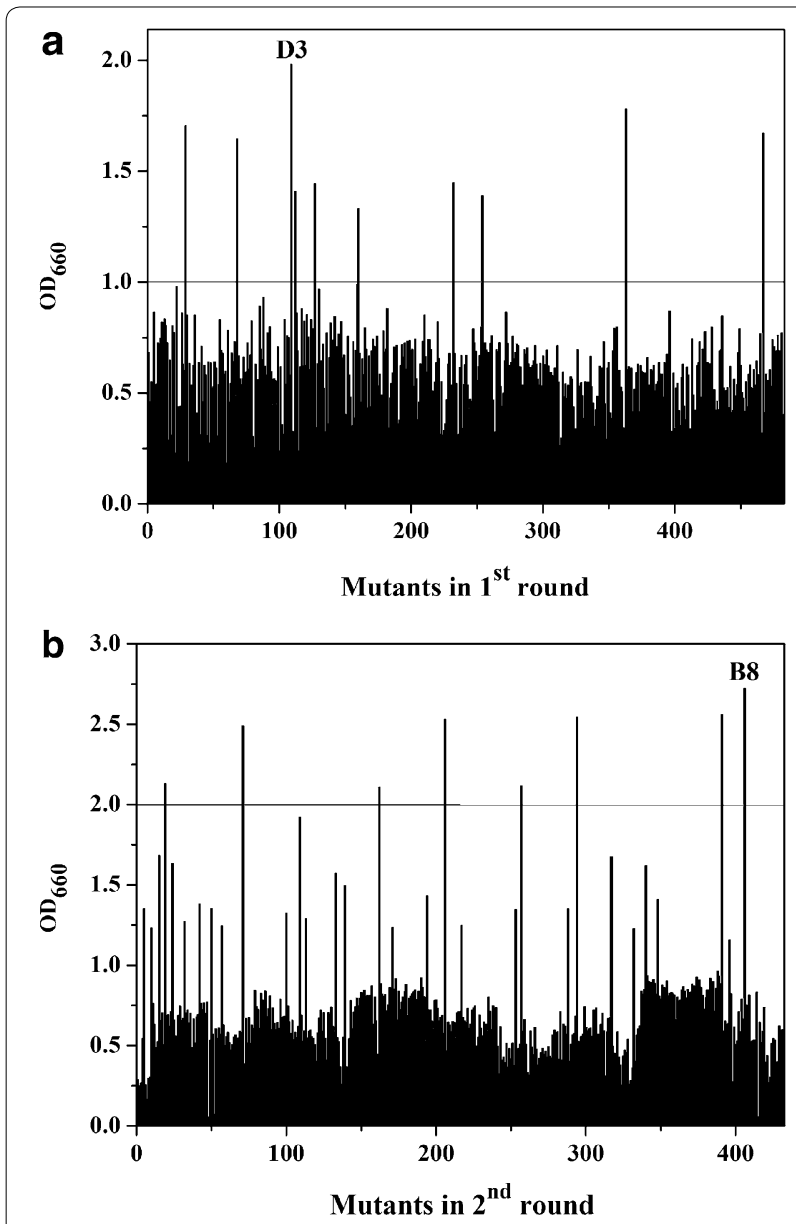

Fig. 1 Screening for $\sigma^{70}$ mutants with high butanol tolerance in the a first round and $\mathbf{b}$ second round. All mutant strains were cultured in 24-well plates at $37^{\circ} \mathrm{C}$ for $8 \mathrm{~h}$, and $0.5 \%(v / v)$ n-butanol was added at $0.2 \mathrm{OD}_{660}$

in the absence of butanol. After treatment with $3 \%(\mathrm{v} / \mathrm{v})$ butanol, WT showed growth only at tenfold dilution, while B8 could grow well at $10^{3}$-fold dilution on LB agar plate, indicating B8 has significantly higher butanol tolerance than WT.

\section{Cell morphology}

The cell morphology of microorganisms can adapt to the environmental changes [26]. Both WT and B8 grew in the absence or presence of butanol. In transmission electron microscope observation (Fig. 3), mutant B8 cells were significantly longer than WT cells after butanol treatment. In the absence of n-butanol, the cell size was $(1.72 \pm 0.17) \times 0.73 \mu \mathrm{m}$ for WT (Fig. 3a) and $(1.89 \pm 0.22) \times 0.87 \mu \mathrm{m}$ for B8 (Fig. 3c), respectively. After $0.8 \%(\mathrm{v} / \mathrm{v})$ n-butanol treatment, the cell size of WT and B8 shifted to $(2.18 \pm 0.25) \times 0.53 \mu \mathrm{m}$ (Fig. 3b) and $(2.94 \pm 0.39) \times 0.52 \mu \mathrm{m}$, respectively (Fig. $3 \mathrm{~d})$, based

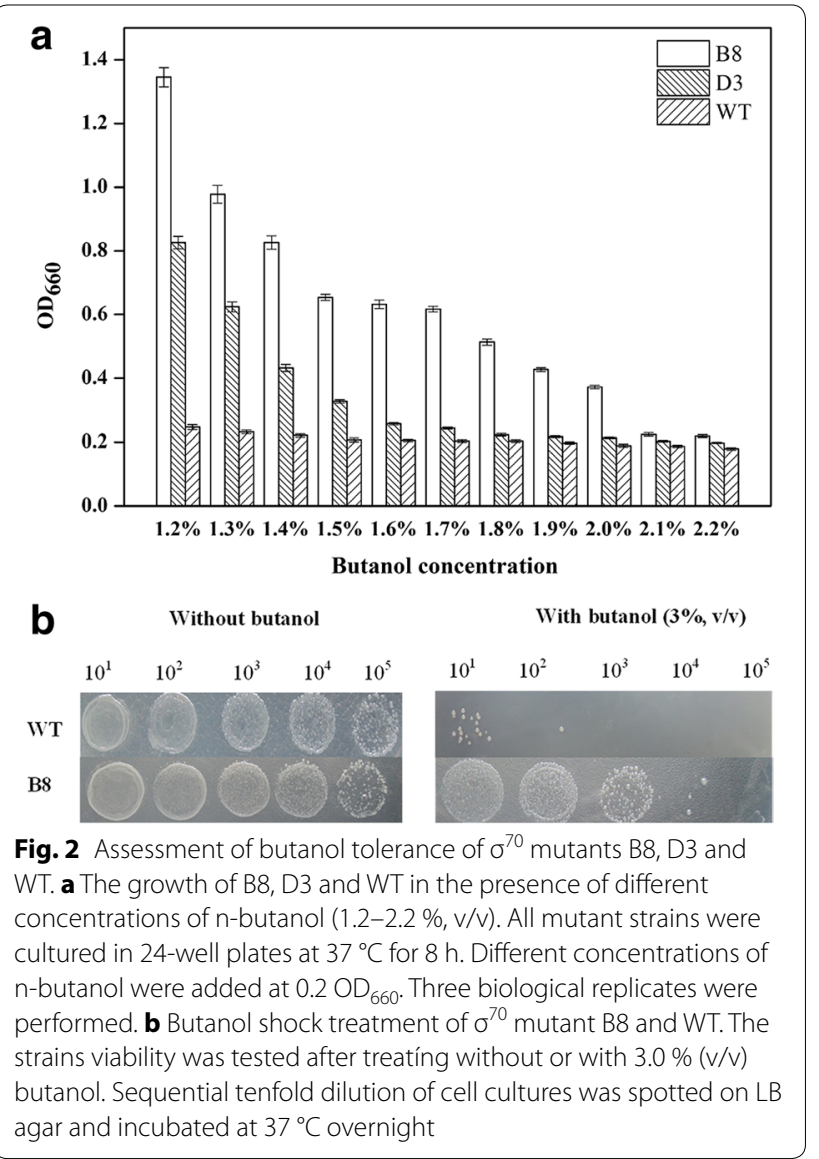

on the measurement of around 100 cells. The changes in cell size were confirmed to be statistically significant $(p<0.05)$. Although the cell morphology was observed based on 100 cells per strain, the cell sizes could also be affected by reasons unrelated to the tolerance effects. Notably, B8 cells were longer than WT when subjected to n-butanol stress. A similar observation on the cell size of ethanol-adapted Saccharomyces cerevisiae has also been reported [27]. Neumann and coworkers reported that the microorganism cells of larger size could be more advantageous over the smaller ones under stress conditions, because the ratio of surface area to volume $\left(\mathrm{S}: \mathrm{V}=4 \pi r^{2}: 4 / 3 \pi r^{3}\right)$ of larger cells is relatively lower than that of the smaller ones [28]. Similarly, B8 cells with smaller $\mathrm{S}: \mathrm{V}$ value exhibited greater butanol tolerance than WT. Meanwhile, it was observed that the cytoplasm of B8 shrank in the presence of butanol. Occasionally, invaginated bodies (Fig. 3d) appeared in B8 and the inner membrane of B8 cells was not broken or leaky under butanol treatment. The huddling cytoplasm in the inner membrane could be a self-protection mechanism which protects the cells from damage due to the solvent [29]. Aono and coworkers also reported a similar 

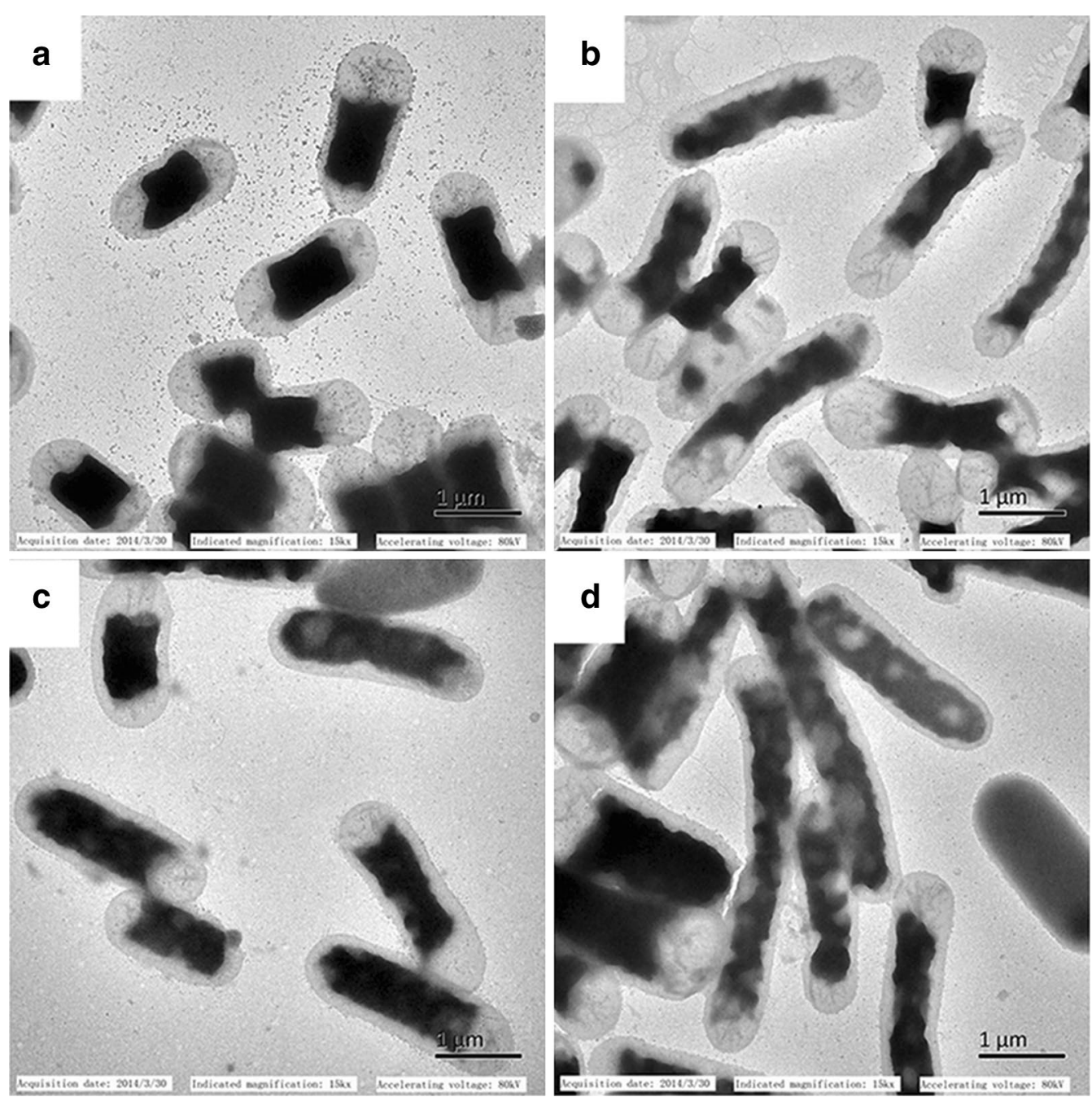

Fig. 3 Transmission electron micrographs of $\sigma^{70}$ mutant B8 and WT cells when cultured without or with $0.8 \%(v / v)$ butanol $(12,000 \times$ magnification). a WT without n-butanol. b WT with n-butanol. c B8 without n-butanol. d B8 with n-butanol

phenomenon in E. coli cell membrane or cytoplasm in the presence of $n$-hexane or cyclohexane [30]. Overall, butanol-tolerant mutant B8 demonstrated a stronger stress response capability. Our results suggest that microbial cells could adapt to solvent stress via morphology change.

\section{DNA microarrays and data analysis}

Organic solvent tolerance-related genes are usually correlated in a precise regulatory network. The global gene expression profile of mutant B8 and WT was analyzed by DNA microarray. Data were analyzed by Gene Spring Software (Santa Clara, CA, USA) to identify differentially expressed genes. For correlation of gene expression difference under solvent challenge, an over twofold change in gene expression was required with a $p$ value $<0.05$
[31]. The results show that 329 genes (including 197 upregulated and 132 down-regulated) exhibited differential expression $(p<0.05 ; \mathrm{FC} \geq 2)$ between $\mathrm{B} 8$ and WT under $0.8 \%(\mathrm{v} / \mathrm{v})$ butanol stress (Additional file 2: Figure S2). Supporting information on the detailed description of differentially expressed genes is provided in Additional file 3: Table S3. Furthermore, genes showing significant difference in transcription level were selected for clustering analysis, which helps to understand the relationships and discrepancy of samples more comprehensively and intuitively (Additional file 4: Figure S3). The same types of genes were gathered in a cluster with similar biological functions.

To identify the function of differentially expressed genes, their biological pathways corresponding to their functional class were summarized by KEGG (Table 1). 
These genes mainly involve in cell envelope biogenesis, carbohydrate metabolism, energy metabolism, nucleotide metabolism and two-component signal transduction system. As shown in Table 1, most genes (such as $y b b Q$, $g l x R, h y i, g c l, g l c B, g l c D, g l c F)$ involved in glyoxylate and dicarboxylate metabolism pathway were up-regulated for over fivefold, and other genes were also enhanced by more than twofold. The glyoxylate and dicarboxylate metabolism pathway could generate ATP, and its intermediate metabolite NADH could assist in regulating proton gradient and membrane potential. This might be a key factor for improving butanol tolerance, because energy supply is essential for overcoming butanol pressure [32]. In addition, genes related to the $A B C$ transporter pathway were also significantly up-regulated by 2.18- to 5.63-fold. ABC transporter systems consist of different transmembrane protein components and share a common ATP-binding site. ABC transporters play roles in bacterial virulence, cell growth and development, and survival under various environments [33, 34]. Based on our microarray data, $\mathrm{ABC}$ transporters annotated as molybdate/arginine/ferric/phosphate type transporters were identified (Table 1), which are responsible for transporting molybdate/arginine/ferric/phosphate substrates across biological membranes. Ferric is important for the regulation of intracellular redox respiratory system, while molybdate/arginine/phosphate substrates are essential for the cellular anabolism and $\mathrm{pH}$ homeostasis [35-38]. Therefore, these $\mathrm{ABC}$ transporters could affect the adaptation of $E$. coli strains under severe environments, such as solvent challenge.

\section{Identification of genes associated with butanol tolerance Analysis of membrane-related down-regulated genes}

Many genes have been confirmed to be related to the organic solvent tolerance of the E. coli strain. For example, overexpression of marA could enhance the function of AcrAB-TolC efflux pump, so that the toxic substances could be extruded more efficiently [21, 39]. Escherichia coli mutant $\triangle$ lon (cell envelop related gene) showed enhanced solvent tolerance level [40]. An E. coli mutant with gene disruptions in both proV and marR showed increased solvent tolerance due to their functions in regulation of osmotic pressure [22]. In this study, seven down-regulated genes ( $y i b T, y g h W, y m g I, y h c N, y r b L$, $E C s 4086, y b j C)$ were selected for further study. They were rarely investigated previously and exhibited over sixfold changes in microarray analysis. All seven genes were annotated as predicted protein or hypothetical protein. The down-regulation folds of these genes are $46.72,13.00,16.02,14.74,14.07,12.91$ and 8.73 , respectively. The knockout strains were constructed for further investigation. Among them, $\triangle y i b T, \triangle y g h W$ and $\triangle y b j C$ exhibited higher n-butanol tolerance, while other knockouts showed similar growth to the control (Fig. 4). So far, there has been no report on the solvent tolerance-related functions of $y g h W$ and $y i b T$. It was, however, noticed that these two predicted proteins are closely related to membrane proteins in stitch networks (http://www.stitch. embl.de/). Stitch is a database which contains interaction information for connected proteins and chemicals. It allows querying by genes name and metabolic pathways [41]. In stitch networks, gns $A$ and gnsB are predicted regulators of phosphatidylethanolamine synthesis and unsaturated fatty acids regulatory proteins, respectively, which are both linked to $y i b T$. Gene $y g h W$ is linked to the inner membrane protein encoding genes $y b j O$ and $y b j M$, as well as genes encoding the predicted lipoprotein or conserved protein in stitch networks. It is therefore presumed that modulation of membrane fatty acid compositions is one possible defense mechanism of $y i b T$ and $y g h W$. It has been reported that the properties of membrane fatty acids, such as fatty acid chain length, branching pattern and unsaturation degree of fatty acids, could change when exposed to environment stress [42-45]. In this study, phospholipids of $\triangle y g h W$ and $\triangle y i b T$ were extracted and analyzed. Our results show that the main components of membrane fatty acids are C16:1, C16:0, C18:0 and C18:1, which account for over $70 \%$ of the total fatty acids in all strains (Table 2) and are responsible for the integrity and fluidity of the membrane [46]. It was noticed that the proportion of unsaturated fatty acid (UFA) in total fatty acids was increased in both knockouts, especially palmitoleic acid (C16:1) and oleic acid (C18:1). Oleic acid (C18:1) has been regarded as the most important UFA in counteracting the toxic effects of the solvent by modulating plasma membrane fluidity [47]. Additionally, palmitoleic acid (C16:1) could influence the rigidity and integrity of membrane lipid bilayer $[46,48]$. It is speculated that a higher proportion of oleic acid and palmitoleic acid in $\triangle y g h W$ and $\triangle y i b T$ contributes to a lower membrane fluidity, higher rigidity and membrane integrity, which might be a compensatory advantage of the membrane challenged by butanol. As a result of changes in membrane fatty acid composition, other physicochemical properties of the membrane, such as proton permeability and lipid-protein interactions could also be affected $[49,50]$. Our findings suggest that the butanol tolerance mechanism of $\triangle y g h W$ and $\triangle y i b T$ are related to membrane fatty acid composition.

Moreover, the hydrophobicity, acidity and alkalinity of cell surface are important properties related to the solvent tolerance [51-53]. Using the MATS method, the adsorptions of three strains $(\triangle y g h W, \triangle y i b T$ and JM109) to organic solvents with different hydrophobicities such as chloroform, hexadecane, ethyl acetate and 
Table 1 KEGG biological pathways of differentially expressed genes

\begin{tabular}{|c|c|c|c|}
\hline KEGG pathway & Gene & $\begin{array}{l}\text { Expression } \\
\text { difference }\end{array}$ & Description \\
\hline \multirow[t]{6}{*}{ ABC transporters } & $\bmod A$ & $2.28 \downarrow$ & Molybdate-binding periplasmic protein precursor \\
\hline & als $B$ & $2.83 \uparrow$ & Putative LACI-type transcriptional regulator \\
\hline & $\operatorname{artM}$ & $2.18 \downarrow$ & Arginine 3rd transport system permease protein \\
\hline & fepc & $2.05 \uparrow$ & ATP-binding component of ferric enterobactin transport \\
\hline & fepD & $5.63 \uparrow$ & Ferric enterobactin transport system permease protein \\
\hline & psts & $2.57 \uparrow$ & Periplasmic phosphate-binding protein \\
\hline \multirow[t]{4}{*}{ Ascorbate and aldarate metabolism } & sgaE & $2.08 \uparrow$ & Putative epimerase \\
\hline & ulaF & $2.56 \uparrow$ & Putative epimerase \\
\hline & ulaA & $2.65 \uparrow$ & Hypothetical protein \\
\hline & ECs5173 & $2.64 \uparrow$ & Putative hexulose-6-phosphate isomerase \\
\hline \multirow[t]{10}{*}{ Glyoxylate and dicarboxylate metabolism } & aceA & $2.97 \uparrow$ & Isocitrate lyase \\
\hline & $y b b Q$ & $7.51 \uparrow$ & 2-Hydroxy-3-oxopropionate reductase \\
\hline & $g / x R$ & $9.86 \uparrow$ & Putative oxidoreductase \\
\hline & $a c e B$ & $3.02 \uparrow$ & Malate synthase A \\
\hline & $\operatorname{acnA}$ & $3.04 \downarrow$ & Aconitate hydrase 1 \\
\hline & hyi & $9.53 \uparrow$ & Glyoxylate-induced protein \\
\hline & $g C l$ & $10.60 \uparrow$ & Glyoxylate carboligase \\
\hline & $g / c B$ & $7.86 \uparrow$ & Malate synthase G \\
\hline & $g / C D$ & $12.78 \uparrow$ & Glycolate oxidase subunit D \\
\hline & $g / C F$ & $22.60 \uparrow$ & Glycolate oxidase iron-sulfur subunit \\
\hline \multirow[t]{3}{*}{ Oxidative phosphorylation } & $\operatorname{atpC}$ & $2.00 \uparrow$ & Membrane-bound ATP synthase \\
\hline & cydA & $2.07 \uparrow$ & Cytochrome d terminal oxidase \\
\hline & $\operatorname{cyd} B$ & $2.18 \uparrow$ & Cytochrome d terminal oxidase polypeptide subunit II \\
\hline \multirow[t]{5}{*}{ Pentose phosphate pathway } & $t k t A$ & $2.31 \uparrow$ & Transketolase 1 \\
\hline & gntK & $2.53 \uparrow$ & Gluconokinase 2 \\
\hline & talA & $2.36 \downarrow$ & Transaldolase A \\
\hline & prs & $2.61 \uparrow$ & Phosphoribosylpyrophosphate synthetase \\
\hline & ECs3810 & $2.19 \uparrow$ & Transketolase 1 isozyme \\
\hline \multirow[t]{2}{*}{ Phenylalanine metabolism } & $m h p D$ & $2.24 \uparrow$ & 2-Keto-4-pentenoate hydratase \\
\hline & $m h p C$ & $2.41 \uparrow$ & 2-Hydroxy-6-ketonona-2,4-dienedioic acid hydrolase \\
\hline \multirow[t]{7}{*}{ Propanoate metabolism } & $t d c D$ & $6.46 \uparrow$ & Putative kinase \\
\hline & $t d c E$ & $6.81 \uparrow$ & Probable formate acetyltransferase 3 \\
\hline & $\operatorname{prpD}$ & $3.39 \downarrow$ & Orf, hypothetical protein \\
\hline & $\operatorname{prpB}$ & $3.72 \downarrow$ & Putative phosphonomutase 2 \\
\hline & $\operatorname{accC}$ & $2.48 \uparrow$ & Acetyl CoA carboxylase \\
\hline & $a c c B$ & $2.23 \uparrow$ & BCCP subunit; carrier of biotin \\
\hline & ECs3995 & $6.59 \uparrow$ & Putative kinase \\
\hline \multirow[t]{9}{*}{ Pyruvate metabolism } & $p o \times B$ & $3.06 \downarrow$ & Pyruvate oxidase \\
\hline & $g / C B$ & $7.86 \uparrow$ & Malate synthase $G$ \\
\hline & $\operatorname{accC}$ & $2.48 \uparrow$ & Acetyl CoA carboxylase \\
\hline & $a c c B$ & $2.23 \uparrow$ & BCCP subunit; carrier of biotin \\
\hline & $g l o B$ & $2.08 \downarrow$ & Probable hydroxyacylglutathione hydrolase \\
\hline & $a c e B$ & $3.02 \uparrow$ & Malate synthase A \\
\hline & pps & $2.12 \uparrow$ & Phosphoenolpyruvate synthase \\
\hline & $t d c E$ & $6.81 \uparrow$ & Probable formate acetyltransferase 3 \\
\hline & ECs0957 & $3.03 \downarrow$ & Pyruvate oxidase \\
\hline \multirow[t]{3}{*}{ Ribosome } & $\operatorname{rps} Q$ & $2.22 \uparrow$ & $30 S$ ribosomal subunit protein $\mathrm{S17}$ \\
\hline & rp/Q & $2.01 \uparrow$ & $50 S$ ribosomal subunit protein L17 \\
\hline & rpmA & $2.01 \uparrow$ & $50 S$ ribosomal subunit protein L27 \\
\hline
\end{tabular}


Table 1 continued

\begin{tabular}{|c|c|c|c|}
\hline KEGG pathway & Gene & $\begin{array}{l}\text { Expression } \\
\text { difference }\end{array}$ & Description \\
\hline & $r p / U$ & $2.28 \uparrow$ & $50 S$ ribosomal subunit protein $\mathrm{L} 21$ \\
\hline & rpmD & $2.04 \uparrow$ & $50 S$ ribosomal subunit protein $L 30$ \\
\hline \multirow[t]{4}{*}{ Starch and sucrose metabolism } & $y b h c$ & $2.06 \uparrow$ & Putative pectinesterase \\
\hline & treF & $2.36 \downarrow$ & Cytoplasmic trehalase \\
\hline & malP & $2.19 \downarrow$ & Maltodextrin phosphorylase \\
\hline & ots $A$ & $2.32 \downarrow$ & Trehalose-6-phosphate synthase \\
\hline \multirow[t]{3}{*}{ Two-component system } & rCSF & $2.40 \uparrow$ & Protein rcsF \\
\hline & ompC & $2.07 \uparrow$ & Outer membrane protein $1 \mathrm{~b}$ \\
\hline & psts & $2.57 \uparrow$ & High-affinity phosphate-specific transport system \\
\hline \multirow[t]{4}{*}{ Ubiquinone and other terpenoid-quinone biosynthesis } & entC & $3.10 \uparrow$ & Isochorismate hydroxymutase 2 \\
\hline & menE & $7.17 \downarrow$ & o-Succinylbenzoate-CoA ligase \\
\hline & ubix & $2.24 \uparrow$ & 3-Octaprenyl-4-hydroxybenzoate carboxy-lyase \\
\hline & menc & $9.10 \downarrow$ & o-Succinylbenzoyl-CoA synthase \\
\hline \multirow[t]{5}{*}{ Phenylalanine. tyrosine and tryptophan biosynthesis } & $\operatorname{trp} E$ & $3.15 \uparrow$ & Anthranilate synthase component I \\
\hline & $\operatorname{trp} D$ & $5.04 \uparrow$ & Anthranilate synthase component II \\
\hline & $\mathrm{aroH}$ & $2.02 \uparrow$ & 3-Deoxy-D-arabinoheptulosonate-7-phosphate synthase \\
\hline & ECs1836 & $2.97 \uparrow$ & Anthranilate synthase component I \\
\hline & ECs1833 & $2.46 \uparrow$ & Tryptophan synthase beta protein \\
\hline
\end{tabular}

“个” Represents up-regulated, “ $\downarrow$ " represents down-regulated

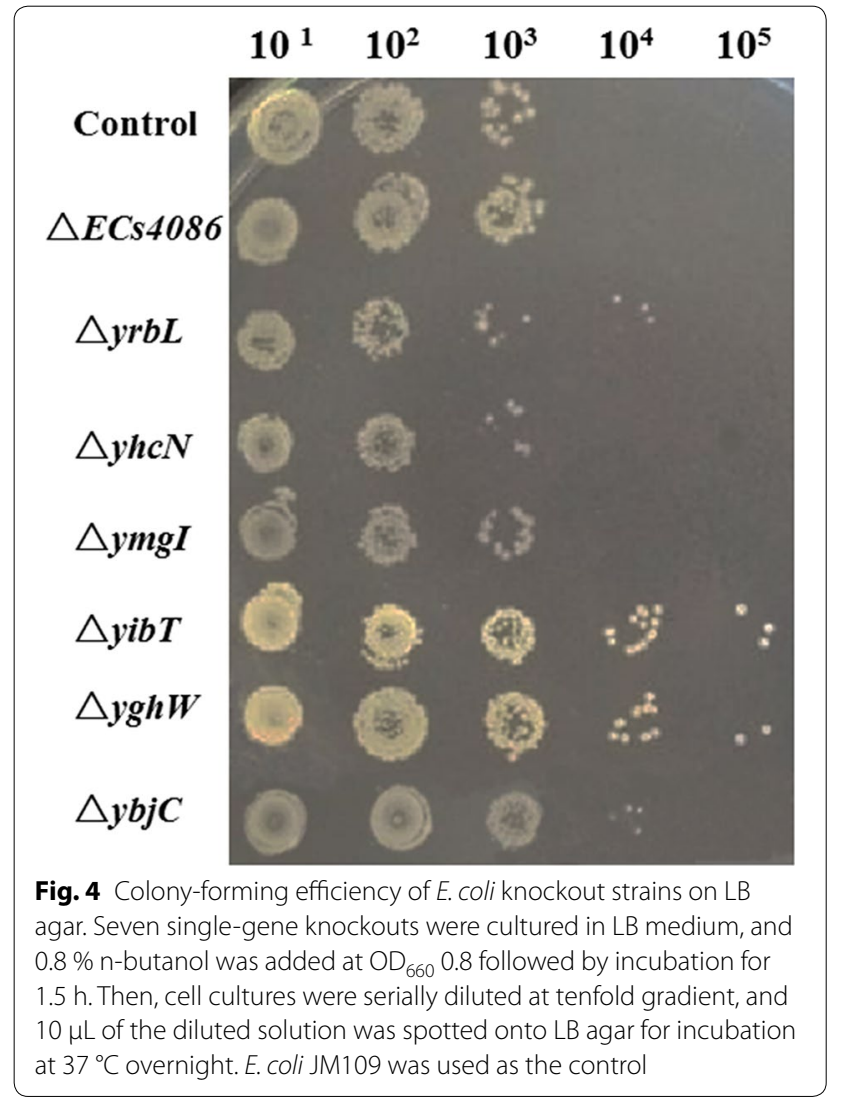

decane were determined (Additional file 5: Figure S4). Our results show that the adsorptions of $\triangle y g h W, \triangle y i b T$ and JM109 to chloroform were 1.89-, 1.86- and 1.61fold of those to hexadecane, indicating that the alkaline strength of the knockout strains was higher than that of WT. The alkaline strength of the cell surface has been reported to be proportional to the adsorption ratio of chloroform adsorption to hexadecane [51]. Similarly, the adsorptions of $\triangle y g h W, \triangle y i b T$ and JM109 to ethyl acetate were 1.81-, 1.79- and 1.65-fold of those to decane. It has also been reported that the acidity strength of cell surface was proportional to the adsorption ratio of ethyl acetate to decane [51]. It is supposed that the increase of surface acidity and alkalinity is due to the presence of proteins and charged chemical groups on the cell surface, such as $\mathrm{PO}_{4}{ }^{2-}$ and $\mathrm{COO}^{-}$[54], which may assist strains to counteract extracellular toxic substances. Additionally, the adhesion to hexadecane and decane reflects the hydrophobicity of the cell surface. In Additional file 5: Figure S4, the adhesion of $\triangle y g h W$ and $\triangle y i b T$ cells to hexadecane and decane was weaker compared with that of the control, suggesting that the surface hydrophobicity of the knockouts was higher than that of the control. The contact angle measurement (CAM) was also conducted to determine the surface hydrophobicity. Our results show that the contact angle of the control, 
Table 2 Comparison of fatty acid composition of knockouts and control

\begin{tabular}{|c|c|c|c|c|c|c|c|}
\hline \multirow{2}{*}{$\begin{array}{l}\text { Major fatty } \\
\text { acids }\end{array}$} & \multicolumn{3}{|c|}{ Fatty acid (\%) } & \multirow{2}{*}{$\begin{array}{l}\text { Difference } \\
\triangle y i b T\end{array}$} & \multirow[t]{2}{*}{$p$ value $^{\mathrm{b}}$} & \multirow{2}{*}{$\begin{array}{l}\text { Difference } \\
\triangle y g h W\end{array}$} & \multirow[t]{2}{*}{$p$ value $^{b}$} \\
\hline & JM109 & $\triangle y i b T$ & $\triangle y g h W$ & & & & \\
\hline C11:0 & $0.20 \pm 0.04$ & $0.00 \pm 0.00$ & $0.13 \pm 0.04$ & -0.20 & $* * *$ & -0.08 & $* *$ \\
\hline C12:0 & $0.69 \pm 0.44$ & $0.33 \pm 0.04$ & $0.45 \pm 0.12$ & -0.36 & * & -0.25 & $*$ \\
\hline C13:0 & $0.00 \pm 0.00$ & $0.05 \pm 0.07$ & $0.07 \pm 0.09$ & 0.05 & * & 0.07 & * \\
\hline C14:0 & $2.24 \pm 0.96$ & $1.42 \pm 0.27$ & $1.41 \pm 0.13$ & -0.82 & * & -0.84 & * \\
\hline C15:0 & $0.65 \pm 0.52$ & $2.45 \pm 0.05$ & $3.03 \pm 0.87$ & 1.80 & $* * *$ & 2.38 & $* * *$ \\
\hline C15:1 & $0.00 \pm 0.00$ & $0.12 \pm 0.16$ & $0.31 \pm 0.07$ & 0.12 & $*$ & 0.31 & $* * *$ \\
\hline C16:0 & $26.96 \pm 1.32$ & $18.86 \pm 0.33$ & $15.48 \pm 1.18$ & -8.10 & $* * *$ & -11.49 & $* * *$ \\
\hline C16:1 & $9.06 \pm 1.08$ & $10.90 \pm 1.05$ & $11.08 \pm 1.52$ & 1.84 & $* *$ & 2.02 & * \\
\hline C17:0 & $1.52 \pm 0.42$ & $6.18 \pm 0.77$ & $5.67 \pm 0.37$ & 4.66 & $* * *$ & 4.15 & $* * *$ \\
\hline C17:1 & $4.69 \pm 0.62$ & $4.80 \pm 0.39$ & $6.35 \pm 0.88$ & 0.11 & * & 1.66 & $* *$ \\
\hline C18:0 & $9.56 \pm 0.95$ & $6.49 \pm 1.44$ & $5.36 \pm 0.31$ & -3.07 & $* *$ & -4.20 & $* * *$ \\
\hline C18:1 & $21.03 \pm 1.36$ & $25.23 \pm 0.73$ & $27.05 \pm 0.37$ & 4.20 & $* * *$ & 6.02 & $* * *$ \\
\hline C18:2 & $0.03 \pm 0.04$ & $0.06 \pm 0.08$ & $0.42 \pm 0.29$ & 0.03 & $*$ & 0.39 & $* *$ \\
\hline C18:3 & $0.38 \pm 0.54$ & $0.00 \pm 0.00$ & $0.04 \pm 0.06$ & -0.38 & * & -0.34 & * \\
\hline C19:1 & $1.22 \pm 0.17$ & $0.08 \pm 0.11$ & $0.07 \pm 0.09$ & -1.14 & $* * *$ & -1.16 & $* * *$ \\
\hline C20:0 & $0.23 \pm 0.01$ & $0.08 \pm 0.11$ & $0.16 \pm 0.06$ & -0.15 & $* *$ & -0.08 & * \\
\hline C20:1 & $1.07 \pm 0.62$ & $0.00 \pm 0.00$ & $0.00 \pm 0.00$ & -1.07 & $* *$ & -1.07 & $* *$ \\
\hline C22:1 & $0.13 \pm 0.18$ & $0.06 \pm 0.08$ & $0.05 \pm 0.07$ & -0.07 & * & -0.08 & * \\
\hline C25:0 & $0.06 \pm 0.08$ & $0.07 \pm 0.09$ & $0.00 \pm 0.00$ & 0.01 & * & -0.06 & * \\
\hline SFA & $42.09 \pm 0.68$ & $35.91 \pm 0.08$ & $31.73 \pm 1.92$ & -6.18 & $* * *$ & -10.37 & $* * *$ \\
\hline UFA & $37.59 \pm 0.51$ & $41.22 \pm 2.28$ & $45.36 \pm 3.34$ & 3.63 & $* *$ & 7.76 & $* * *$ \\
\hline
\end{tabular}

a The values represent percentages of total fatty acids and are means \pm standard deviations from three independent experiments

b Statistical significance between knockout and control strain (E.coli JM109)

${ }^{*} p>0.05,{ }^{* *} 0.01<p<0.05,{ }^{* * *} p<0.01$

$\triangle y g h W$ and $\triangle y i b T$ were $21.17 \pm 1.78^{\circ}, 36.25 \pm 2.13^{\circ}$ and $34.65 \pm 2.04^{\circ}$, respectively (Additional file 6: Figure S5). Consistent with the results of MATS, CAM assay represents a higher surface hydrophobicity of $\triangle y g h W$ and $\triangle y i b T$. Other studies suggest that the expansion of surface hydrophobic region could promote the interactions between the phospholipids and embedded proteins and bonds between cation and electronegative phospholipids in the membrane $[55,56]$. It is therefore rational to conjecture that the cell surface of $\triangle y g h W$ and $\triangle y i b T$ is less permeable, which could help to prevent the intruding of toxicity compounds.

The gene $(y b j C)$ encoding a predicted inner membrane protein was also investigated. To verify the location of $\mathrm{YbjC}$ and its tolerance-related mechanism, YbjC-GFP (green fluorescent protein) fusion protein was constructed. As shown in Fig. 5a, a clear fluorescence signal surrounding the membrane region was detected in $E$. coli cells expressing fusion protein YbjC-GFP. Differently, the entire cells were filled with green fluorescence when GFP was expressed alone (Fig. 5b). Here, a known membrane protein YidC fused with GFP was expressed as the positive control (Fig. 5c), and the microscopy pattern of YbjC-GFP fusion was similar to YidC-GFP. This further suggests that $\mathrm{YbjC}$ is a membrane protein. Unfortunately, the function of YidC related to the butanol tolerance mechanism is not clear yet.

\section{Analysis of carboxylic acid metabolism-related up-regulated genes}

Gene cluster $g l c$, encoding enzymes involved in glyoxylate and dicarboxylate metabolism, was up-regulated significantly in this study. For example, genes $g l c F, g l c A$, $g l c D, g l c G, g l c B$ and $g c l$ were up-regulated by $22.60-$, 18.17-, 12.78-, 12.75- 7.86- and 10.60-fold, respectively. The above genes and the $g l c$ gene cluster were selected for overexpression to investigate their functional relevance to butanol tolerance. As shown in Additional file 7: Figure S6, $g l c A$ overexpression strain could barely grow even without butanol. For $g l c B, g l c D$ and $g l c G$ overexpression strains, similar growth with control strain (JM109 carrying empty plasmid PQE80L) was observed in the presence and absence of butanol. Strains overexpressing $g l c F$ and $g c l$ showed improved cell growth 

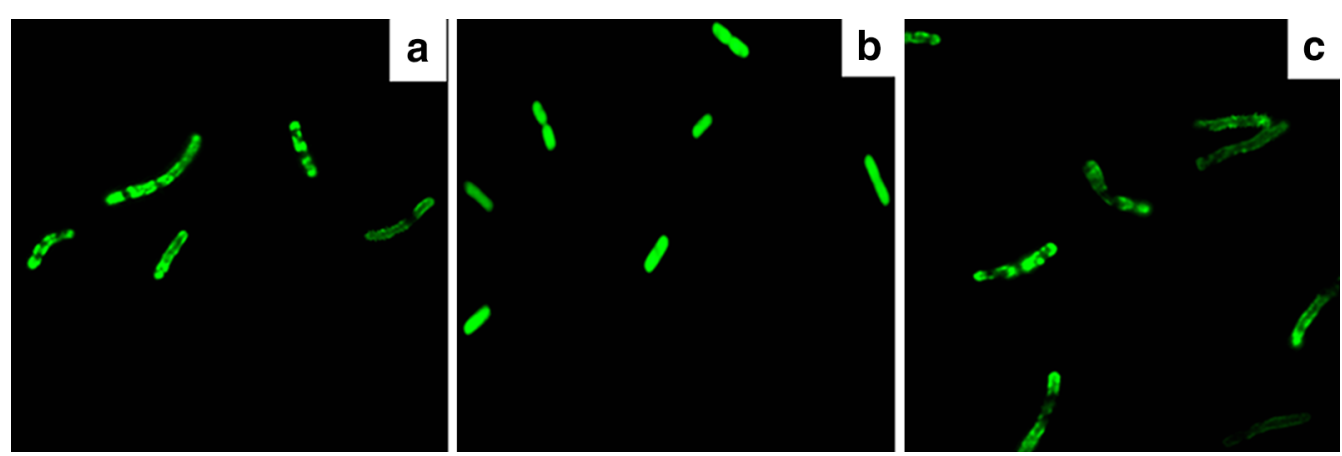

Fig. 5 Fluorescent micrographs of recombinant E. coli cells expressing a YbjC-PPP-GFP fusion protein, $\mathbf{b}$ GFP protein (negative control) and $\mathbf{c} Y i d C-$ PPP-GFP fusion protein (positive control) (1000x magnification)

compared with the control. Furthermore, glcDEFGBA cluster co-expression strains also exhibited better growth than the control with or without butanol. The possible explanation is that $g l c A$ encodes glycolate transporter, and its overexpression could result in metabolism imbalance of carbon source and energy in cells [57]. $g l c B$ encodes malate synthase $G$ which is not essential for growth. $g l c D$ and $g l c G$ encode different subunits of glycolate oxidase, which have no significant effect on the oxidase activity [58]. Gene $g l c F$ encodes iron-sulfur subunit of glycolate oxidase that catalyzes the conversion of glycolate to glyoxylate, and $\mathrm{gcl}$ encodes glyoxylate carboligase that transforms glyoxylate into phosphoglycerate $[59,60]$. One possible explanation is that these two enzymes, glycolate oxidase and glyoxylate carboligase, directly improve the TCA cycle via modulating glyoxylate and pyruvate, which replenish metabolic intermediates for the TCA cycle (Additional file 8: Figure S7). In this study, rpoD mutagenesis approach conduced to enhanced OST phenotype by regulating the expression level of hundreds of genes. Our results also suggest that the co-expression of $g l c$ gene cluster is more favorable for cell growth than individual gene overexpression, which might have minor or negative effect on butanol tolerance. To elucidate the possible mechanism, the concentrations of carboxylic acids in TCA cycle were monitored in $g l c F$ and $g c l$ overexpression strains. For both strains, pyruvate concentrations were increased in the presence of butanol, whereas higher pyruvate levels were also observed without butanol (Additional file 9: Table S4). Moreover, the fumarate concentration was also increased in the overexpression strains without butanol, but declined slightly when $0.8 \%(\mathrm{v} / \mathrm{v})$ butanol was added. This phenomenon may be attributed to the inhibition of certain TCA cycle enzymes (such as succinate dehydrogenase) that are sensitive to the oxidative stress induced by butanol. A similar phenomenon was reported by $\mathrm{Fu}$ and coworkers [32].
Although the elevated pyruvate level in $g c l$ and $g l c F$ overexpression strains does not seem to be directly related to butanol stress, it is assumed that the up-regulation of these two genes is favorable for the cell growth by replenishing TCA metabolic intermediates.

\section{Conclusions}

In summary, we successfully isolated an $E$. coli strain harboring rpoD mutant B8 with $2 \%$ (v/v) butanol tolerance using global transcriptional machinery engineering approach. Based on DNA microarrays results, 329 genes (including 197 up-regulated and 132 down-regulated) showed over twofold difference in the expression level compared with WT after butanol treatment. These genes are mainly involved in the metabolic pathways including ABC pump, ascorbate and aldarate metabolism, energy metabolism, two-component signal transduction system and amino acid metabolism. Tolerance mechanisms of several critical genes have been elucidated. Among them, down-regulated genes $y g h W$ and $y i b T$ were proved to improve n-butanol tolerance due to their regulatory roles in membrane fatty acids composition. YbjC was confirmed to be a membrane protein, while up-regulated genes $g c l$ and $g l c F$ could replenish TCA cycle metabolic intermediates to improve cell growth and metabolism. These results could provide the potential approach for the construction of $E$. coli strain as a bio-butanol producer.

\section{Methods}

Strains, plasmids and culture conditions

Escherichia coli JM109 was used as the host strain. Gene deletion strains were generated by Red-mediated recombination approach and overexpression strains were generated using $\mathrm{pQE} 80 \mathrm{~L}$ as an expression vector. Strains and plasmids are listed in Additional file 10: Table S1. Primers used in this study are listed in Additional file 11: Table S2. Plasmid $\mathrm{pQE} 80 \mathrm{~L}$ was purchased from Qiagen $\mathrm{GmbH}$ 
(Hilden, Germany). pHACM-rpoD ${ }^{\mathrm{WT}}$ was presented as a kind gift of Dr. Huimin Yu (Tsinghua University, China). Restriction enzymes and PrimeSTAR ${ }^{\circledR} \mathrm{HS}$ DNA Polymerase were purchased from Takara (Tokyo, Japan). The dam-methylated DNA-specific restriction enzyme $D p n \mathrm{I}$ was purchased from New England Biolabs (Ipswich, MA, USA). GeneMorph II Random Mutagenesis Kit was obtained from Stratagene (La Jolla, CA, USA).

All strains were grown in Luria-Bertani (LB) medium (tryptone $10 \mathrm{~g} / \mathrm{L}$, yeast extract $5 \mathrm{~g} / \mathrm{L}, \mathrm{NaCl} 10 \mathrm{~g} / \mathrm{L}$ ) at $37^{\circ} \mathrm{C}, 120 \mathrm{rpm}$. Butanol was added as specified in each experiment. When necessary, antibiotics chloramphenicol $(34 \mu \mathrm{g} / \mathrm{mL})$, ampicillin $(100 \mu \mathrm{g} / \mathrm{mL})$ and kanamycin $(50 \mu \mathrm{g} / \mathrm{mL})$ were added to the media. For gene overexpression, $0.2 \mathrm{mM}$ IPTG was added to the medium at around $0.3 \mathrm{OD}_{660}$.

\section{Construction of random mutagenesis library}

Using plasmid pHACM-rpo ${ }^{\mathrm{WT}}$ as the template, random mutagenesis was performed by the GenemorphII Random Mutagenesis kit (Stratagene) with a mutation rate of approximately 4.5-9 mutations $/ \mathrm{kb}$. The error-prone PCR program was set as follows: $5 \mathrm{~min}$ at $95^{\circ} \mathrm{C}, 30$ cycles of $95{ }^{\circ} \mathrm{C}$ for $30 \mathrm{~s}, 57^{\circ} \mathrm{C}$ for $1 \mathrm{~min}$, followed by $72{ }^{\circ} \mathrm{C}$ for $2 \mathrm{~min}$, and $10 \mathrm{~min}$ at $72{ }^{\circ} \mathrm{C}$. After running the whole plasmid PCR, the PCR product mixture was digested with $D p n I$ and then transformed into E. coli JM109. Escherichia coli transformants were plated on LB agar plates containing $34 \mu \mathrm{g} / \mathrm{mL}$ chloramphenicol and incubated at $37{ }^{\circ} \mathrm{C}$. Then the colonies were scraped off to create a $\sigma^{70}$ mutant library for further butanol-tolerant phenotype selection. The total mutant library size was approximately $10^{6}$.

\section{Phenotype selection of $\mathbf{n}$-butanol-tolerant mutants The first round of screening}

First, 483 colonies were selected from the $\sigma^{70}$ mutant library on agar plate containing $0.5 \%$ butanol (v/v). Then, these colonies were inoculated into 24-well plates with $\mathrm{LB} / \mathrm{Cm}$ liquid medium. Butanol $(0.5 \%$, v/v) was added into the culture when $\mathrm{OD}_{660}$ reached 0.2, and the cells were further incubated for $8 \mathrm{~h}$ at $120 \mathrm{rpm}$ and $37{ }^{\circ} \mathrm{C}$. Cell density was measured, and ten mutants with $\mathrm{OD}_{660}$ above 1.0 were selected. Then, the selected mutants were cultured in a medium containing higher concentrations $(0.5-1.5 \%$, v/v) of $n$-butanol by $0.1 \%(\mathrm{v} / \mathrm{v})$ gradient, until a strain exhibiting the highest tolerance was obtained. The plasmid harboring the rpoD mutant was then sequenced and designated as D3.

\section{The second round of screening}

To further improve the n-butanol tolerance, $\sigma^{70}$ mutant D3 was used as a template to construct a random mutagenesis library for a second round of screening. The screening method was the same as that in the first round. The best mutant B8 was selected and evaluated under higher n-butanol concentrations $(0.1 \%$ gradient increasing from 1.2 to $2.2 \%$ ) to determine its maximum tolerant level.

\section{Solvent shock treatment}

The overnight cell culture was inoculated $(1 \%)$ into a fresh LB medium. When $\mathrm{OD}_{660}$ reached $0.8,3 \%(\mathrm{v} / \mathrm{v})$ $\mathrm{n}$-butanol was added into the culture. After incubation at $37^{\circ} \mathrm{C}$ for $1.5 \mathrm{~h}$, the cultures were serially diluted for $10^{5}$, $10^{4}, 10^{3}, 10^{2}$ and 10 -fold with aseptic water. Then, $10 \mu \mathrm{L}$ of the each diluted culture was spotted onto LB/agar plates and further incubated at $37^{\circ} \mathrm{C}$ overnight.

\section{Cell morphology}

The $\sigma^{70}$ mutant B8 and WT strains were cultured overnight and inoculated $(1 \%)$ into fresh $\mathrm{LB} / \mathrm{Cm}$ liquid medium for incubation at $37^{\circ} \mathrm{C}$ and $120 \mathrm{rpm}$ for $8 \mathrm{~h}$ with or without $0.8 \%(\mathrm{v} / \mathrm{v}) \mathrm{n}$-butanol. The cells were diluted and spread on $\mathrm{LB} / \mathrm{Cm}$ agar plates. Single colonies were treated as described in the literature and observed using transmission electron microscope [30]. Briefly, single colonies were picked and fixed by immersion in $2.5 \%$ glutaraldehyde at $4{ }^{\circ} \mathrm{C}$ for $3 \mathrm{~h}$. The cell suspension was mixed once every half-hour. Then, cells were washed four times with $0.1 \mathrm{M}$ phosphate buffer ( $\mathrm{pH} 7.2$ ), and the samples were diluted for cell morphology observation under Hitachi-H7650 transmission electron microscopy (Japan). The average cellular size of WT and B8 was counted on the electron microscope based on around 100 cells.

\section{DNA microarrays}

Escherichia coli strains harboring $\sigma^{70}$ mutant B8 and WT were cultured overnight and inoculated (1\%) into fresh medium. n-Butanol $(0.8 \%, \mathrm{v} / \mathrm{v})$ was added at $0.8 \mathrm{OD}_{660}$ and further incubated for $1.5 \mathrm{~h}$. Cells were harvested by centrifugation $\left(8800 \mathrm{~g}, 4{ }^{\circ} \mathrm{C}\right)$. Total RNA was extracted using Qiagen RNeasy kit (Hilden, Germany) following the manufacturer's instructions. Qualified total RNA was further purified by Qiagen RNeasy mini kit and RNaseFree DNase Set. Three biological replicates of RNA samples were stored in dry ice and subjected to further DNA microarray analysis. The microarray service was provided by Shanghai Biotechnology Co., Ltd. (Shanghai, China) using Agilent SurePrint E. coli $8 \times 15 \mathrm{~K}$ slides, and the quality and integrity of RNA were examined before analysis.

Slides were scanned by Agilent Microarray Scanner (Santa Clara, CA, USA), and data were extracted with Agilent Feature Extraction software 10.7. Raw data were 
normalized by Quantile algorithm, Gene Spring Software 11.0 (Santa Clara, CA, USA). Differentially expressed genes were identified using the rank product method [61]. The MeV (TM4) software was used for clustering and other expression profile analysis [62]. The related metabolic pathway of differentially expressed genes was analyzed using Kyoto Encyclopedia of Gene and Genomics (KEGG) database [63]. The microarray data have been deposited at the gene expression omnibus (GEO) under the accession number GSE79305.

\section{Assay of $\mathbf{n}$-butanol sensitivity of knockout and overexpression strains}

Gene knockout (for down-regulated genes) and overexpression (for up-regulated genes) strains were constructed based on the microarrays results. Spot assay as a tolerance confirmation method was conducted for knockout strains. n-Butanol $(0.8 \%, \mathrm{v} / \mathrm{v})$ was added when the cell density reached $0.8 \mathrm{OD}_{660}$, then the cells were further cultured for $1.5 \mathrm{~h}$. Cell culture was serially diluted at a tenfold gradient, and $10 \mu \mathrm{L}$ of the diluted culture was spotted onto LB/agar plates for incubation at $37^{\circ} \mathrm{C}$ overnight. For overexpression strains, the overnight culture was inoculated (1\%) into fresh medium and cultured at $37{ }^{\circ} \mathrm{C}$ and $120 \mathrm{rpm}$, and $0.2 \mathrm{mM}$ IPTG was added when $\mathrm{OD}_{660}$ reached 0.3 . Then, $0.8 \%(\mathrm{v} / \mathrm{v})$ butanol was added at $0.8 \mathrm{OD}_{660}$ for further incubation at $30{ }^{\circ} \mathrm{C}$ for $8 \mathrm{~h}$. The growth of the strains was monitored by measuring cell density at $\mathrm{OD}_{660}$.

\section{Lipid extraction}

Lipid extraction was performed as described by Bligh [64]. Briefly, the stationary phase cells of E. coli JM109, $\triangle y i b T$ and $\triangle y g h W$ were collected by centrifugation and washed with $10 \mathrm{mM}, \mathrm{pH} 7.4$ sodium phosphate buffer. The cell pellets ( $0.3 \mathrm{~g}$ wet weight) were suspended in a mixture consisting of buffer, methanol and chloroform in the proportion of 0.8:2:1 (v/v) and incubated at room temperature for $2 \mathrm{~h}$, with brief shaking every half-hour. Then, the extract was centrifuged at $4{ }^{\circ} \mathrm{C}$ after diluting with methanol and chloroform $(1: 1, \mathrm{v} / \mathrm{v})$. The lower chloroform phase (containing lipids) was added into the methanol solution containing $5 \%(\mathrm{v} / \mathrm{v}) \mathrm{H}_{2} \mathrm{SO}_{4}$. After $2 \mathrm{~h}$ of methylation at $70{ }^{\circ} \mathrm{C}$, the mixture was cooled to room temperature and extracted three times with pentane. Then, the samples were air dried to remove pentane. Finally, the samples were reconstituted with $\mathrm{n}$-hexane for $\mathrm{GC}-\mathrm{MS}$ analysis.

\section{Determination of cell surface hydrophobicity}

MATS (microbial adhesion to solvents) analysis was performed following the MATH method developed by Bellon-Fontaine with slight modification [53, 65]. Briefly, the strains were cultured in LB medium, and butanol
$(0.8 \%, \mathrm{v} / \mathrm{v})$ was added when $\mathrm{OD}_{660}$ reached 0.8 . Cells were further incubated for $12 \mathrm{~h}$ at $37{ }^{\circ} \mathrm{C}$ and were collected by centrifugation $\left(8800 \mathrm{~g}\right.$ and $10 \mathrm{~min}$ at $\left.4{ }^{\circ} \mathrm{C}\right)$, then washed with $100 \mathrm{mM}, \mathrm{pH} 6.0$ potassium phosphate buffer and centrifuged again. The cell concentration was then adjusted to around 1.0 $\mathrm{OD}_{400}\left(\mathrm{~A}_{0}\right)$ using the same potassium phosphate buffer. The cell suspension $(4.8 \mathrm{~mL})$ was mixed with $0.8 \mathrm{~mL}$ of chloroform, hexadecane, ethyl acetate and decane, respectively. The two-phase mixture was mixed by vortexing for $90 \mathrm{~s}$ and then incubated statically at room temperature for $15 \mathrm{~min}$. The aqueous phase was removed and $\mathrm{OD}_{400}$ was measured (A) to calculate the adhesion ratio [Adhesion $\%=\left(1-\mathrm{A} / \mathrm{A}_{0}\right) \times 100 \%$ ] The above experiment was repeated for three times.

Contact angle measurements (CAM) was performed to measure the surface hydrophobicity [51]. Briefly, strains were cultured in the LB medium, and butanol $(0.8 \%, \mathrm{v} / \mathrm{v})$ was added when $\mathrm{OD}_{660}$ reached 0.8. Cells were further incubated for $12 \mathrm{~h}$ at $37{ }^{\circ} \mathrm{C}$ and were collected by centrifugation at $8800 \mathrm{~g}$ for $10 \mathrm{~min}$ at $4{ }^{\circ} \mathrm{C}$ and washed twice by $0.85 \%$ saline. Then, the concentration of cell suspension was adjusted to $50 \mathrm{mg}$ wet cells/mL, and $10 \mathrm{~mL}$ cells suspension was filtered through polyvinylidene difluoride membrane $(0.22 \mu \mathrm{m}, 50 \mathrm{~mm}$ in diameter $)$ under vacuum. For each strain, three biological replicates were performed and measured independently. The contact angle was measured in three phases: the bacterial lawn, n-tetradecane and a droplet of distilled water using a contact angle meter (Dataphysics, Germany).

\section{Analytical methods}

\section{Fatty acid component analysis}

The fatty acid component analysis was performed as previously described $[66,67]$. The fatty acid profile was assessed with Trace1310 GC equipped with TSQ8000 MSD (Thermo Fisher Scientific, Massachusetts, USA) and an HP-5MS methylpolysiloxane phase column $(30 \mathrm{~m} \times 0.25 \mathrm{~mm} \times 0.25 \mu \mathrm{m})$. The $\mathrm{GC}$ conditions are as follows: the initial temperature of $60^{\circ} \mathrm{C}$ for $2 \mathrm{~min}, 8{ }^{\circ} \mathrm{C} /$ min to $150{ }^{\circ} \mathrm{C}$, then to $250{ }^{\circ} \mathrm{C}$ at a rate of $3{ }^{\circ} \mathrm{C} / \mathrm{min}$, finally at $10^{\circ} \mathrm{C} / \mathrm{min}$ to $280^{\circ} \mathrm{C}$ and held for $5 \mathrm{~min}$. Fatty acids and other volatile compounds were identified by mass spectral library search.

\section{Quantification of pyruvate and fumarate}

Overexpression strains and control (JM109 carrying empty plasmid $\mathrm{pQE80L}$ ) were cultured overnight and inoculated into fresh LBG medium $(1 \%, v / v)$. IPTG $(0.2 \mathrm{mM})$ was added at $0.3 \mathrm{OD}_{660}$, cells were further cultured for $8 \mathrm{~h}$ with or without $0.8 \% \mathrm{n}$-butanol. The cell culture was centrifuged and the supernatant was subjected to HPLC analysis using Agilent 1260 (Palo Alto, USA) equipped with an Agilent Hi-Plex H PL1170-6830 
column $(7.7 \times 300 \mathrm{~mm}, 8 \mu \mathrm{m})$ at $55^{\circ} \mathrm{C} .5 \mathrm{mM} \mathrm{H}_{2} \mathrm{SO}_{4}$ was used as an eluent at a flow rate of $0.6 \mathrm{~mL} / \mathrm{min}$.

\section{Additional file}

Additional file 1: Fig. S1. Cell growth of $\sigma^{70}$ mutants and WT in the presence of $1.2 \%(\mathrm{v} / \mathrm{v}) \mathrm{n}$-butanol. All mutant strains were cultured in 24-well plates at $37^{\circ} \mathrm{C}$ for $8 \mathrm{~h}, 1.2 \%(\mathrm{~V} / \mathrm{V}) \mathrm{n}$-butanol were added at $0.2 \mathrm{OD}_{660}$.

Additional file 2: Fig. S2. Volcano plot of global gene expression differences between $\sigma^{70}$ mutant B8 and WT upon butanol challenge. $X$ axis: $\log _{2}$ (Fold Change); Y axis: - Log 10 ( $p$-value). Green lines parallel to $X$ axis represents $p$-value $=0.05$. The left red zone denotes the number of down-regulated genes; the right red zone denotes the number of upregulated genes $(p<0.05 ; F C \geq 2)$.

Additional file 3: Table S3. Genes significantly changed (fold change $\geq 2$, p-value $<0.05)$ in B8 vs control with $0.8 \%(v / v)$ butanol treatment.

Additional file 4: Fig. S3. Transcription profile analysis of genes exhibiting significantly different expression levels in $\sigma^{70}$ mutant B8 and WT. Hierarchical clustering using differentially expressed genes (probe sets) $(p<0.05 ; F C \geq 2$ ). Abscissa represents samples of B8 and WT, the ordinate represents different genes. Three biological replicates were performed.

Additional file 5: Fig. S4. Analysis of surface hydrophobicity of $E$. coli knockout strains $\triangle y g h W, \triangle y i b T$ and JM109 (control) by MATS. Three biological replicates were performed.

Additional file 6: Fig. S5. Contact angle measurement of E. coli knockout strains (A) JM109 (control), (B) $\triangle y g h W$, and (C) $\triangle$ yibT. Three biological replicates were performed.

Additional file 7: Fig. S6. Analysis of $n$-butanol tolerance of various gene overexpression strains with or without $0.8 \%$ n-butanol. Strains were pre-cultured at $37^{\circ} \mathrm{C}$ with addition of $0.2 \mathrm{mM} \mathrm{IPTG}$ at $0.3 \mathrm{OD}_{660}$. Then $0.8 \%(\mathrm{~V} / \mathrm{v})$ butanol was added at $0.8 \mathrm{OD}_{660}$ for further incubation at $30^{\circ} \mathrm{C}$ for $8 \mathrm{~h}$. Three biological replicates were performed.

Additional file 8: Fig. S7. Pathways of glycolate metabolism and tricarboxylic acid cycle in Escherichia coli.

Additional file 9: Table S4. Pyruvate and fumarate levels in cell cultures of gcl and glcF overexpression strains with or without butanol.

Additional file 10: Table S1. Strains and plasmids used in this study.

Additional file 11: Table S2. Primes used in this study.

\section{Abbreviations}

gTME: global transcription machinery engineering; KEGG: Kyoto Encyclopedia of Gene and Genomics; UFA: unsaturated fatty acid; SFA: saturated fatty acid; MATS: microbial adhesion to solvents; CAM: contact angle measurement; GFP: green fluorescent protein.

\section{Authors' contributions}

HS carried out the DNA microarray data analysis, solvent tolerant, membrane lipid analysis, cell surface hydrophobicity and quantification of metabolites, and drafted the manuscript. FZ carried out screening of $\sigma^{70}$ mutants, DNA microarray sample preparation, transmission electron microscopy and participated in drafting the manuscript. AW carried out gene knockout/overexpression experiments and analyzed the data. $\mathrm{RH}$ participated in the design of the study, analyzed the data and helped to revise the manuscript. GX helped to design the experiments and revise the manuscript. YN conceived the study, designed and coordinated the experiments and critically revised the manuscript. All authors read and approved the final manuscript.

\section{Acknowledgements}

We thank Mr. Kang Wu and Prof. Xiaodong Gao for help with the transmission electron micrographs and fluorescent micrograph analysis.

\section{Availability of supporting data}

The microarray data have been deposited at Gene Expression Omnibus (http://www.ncbi.nlm.nih.gov/geo/info/submission.html) under the accession number GSE79305.

\section{Competing interests}

The authors declare that they have no competing interests.

\section{Funding}

We are grateful to the National Natural Science Foundation of China (21276112, 31401634), Natural Science Foundation of Jiangsu Province (BK20150003, BK20140135), Fundamental Research Funds for the Central Universities (JUSRP51409B), the Program of Introducing Talents of Discipline to Universities (111-2-06) and a project funded by the Priority Academic Program Development of Jiangsu Higher Education Institutions for the financial support of this research.

Received: 7 January 2016 Accepted: 11 May 2016

Published online: 01 June 2016

\section{References}

1. Bruno TJ, Wolk A, Naydich A. Composition-explicit distillation curves for mixtures of gasoline with four-carbon alcohols (butanols). Energy Fuels. 2009;23:2295-306.

2. Atsumi S, Cann AF, Connor MR, Shen CR, Smith KM, Brynildsen MP, Chou $\mathrm{KJ}$, Hanai T, Liao JC. Metabolic engineering of Escherichia coli for 1-butanol production. Metab Eng. 2008;10(6):305-11.

3. Baez A, Cho KM, Liao JC. High-flux isobutanol production using engineered Escherichia coli: a bioreactor study with in situ product removal. Appl Microbiol Biotechnol. 2011;90(5):1681-90.

4. Inoue A, Horikoshi K. Estimation of solvent-tolerance of Bacteria by the solvent parameter Log-P. J Ferment Bioeng. 1991;71(3):194-6.

5. Atsumi S, Hanai T, Liao JC. Non-fermentative pathways for synthesis of branched-chain higher alcohols as biofuels. Nature. 2008;451(7174):86-9.

6. Bajwa PK, Shireen T, D'Aoust F, Pinel D, Martin VJ, Trevors JT, Lee H. Mutants of the pentose-fermenting yeast Pichia stipitis with improved tolerance to inhibitors in hardwood spent sulfite liquor. Biotechnol Bioeng. 2009;104(5):892-900.

7. Geddes CC, Mullinnix MT, Nieves IU, Peterson JJ, Hoffman RW, York SW, Yomano LP, Miller EN, Shanmugam KT, Ingram LO. Simplified process for ethanol production from sugarcane bagasse using hydrolysate-resistant Escherichia coli strain MM160. Bioresour Technol. 2011;102(3):2702-11.

8. Shi DJ, Wang CL, Wang KM. Genome shuffling to improve thermotolerance, ethanol tolerance and ethanol productivity of Saccharomyces cerevisiae. J Ind Microbiol Biotechnol. 2009;36(1):139-47.

9. Tomas CA, Beamish J, Papoutsakis ET. Transcriptional analysis of butanol stress and tolerance in Clostridium acetobutylicum. J Bacteriol. 2004;186(7):2006-18.

10. Alper H, Moxley J, Nevoigt E, Fink GR, Stephanopoulos G. Engineering yeast transcription machinery for improved ethanol tolerance and production. Science. 2006;314(5805):1565-8.

11. Alper H, Stephanopoulos G. Global transcription machinery engineering: a new approach for improving cellular phenotype. Metab Eng. 2007;9(3):258-67.

12. Klein-Marcuschamer D, Stephanopoulos G. Assessing the potential of mutational strategies to elicit new phenotypes in industrial strains. Proc Natl Acad Sci USA. 2008;105(7):2319-24.

13. Zhang $H$, Chong $H$, Ching CB, Song H, Jiang R. Engineering global transcription factor cyclic AMP receptor protein of Escherichia coli for improved 1-butanol tolerance. Appl Microbiol Biotechnol. 2012;94(4):1107-17.

14. Liu H, Yan M, Lai C, Xu L, Ouyang P. gTME for improved xylose fermentation of Saccharomyces cerevisiae. Appl Biochem Biotechnol. 2010;160(2):574-82

15. Hong SH, Lee J, Wood TK. Engineering global regulator Hha of Escherichia coli to control biofilm dispersal. Microb Biotechnol. 2010;3(6):717-28.

16. Malhotra A, Severinova E, Darst SA. Crystal structure of a sigma 70 subunit fragment from E. coli RNA polymerase. Cell. 1996;87(1):127-36. 
17. Owens JT, Miyake R, Murakami K, Chmura AJ, Fujita N, Ishihama A, Meares CF. Mapping the sigma70 subunit contact sites on Escherichia coli RNA polymerase with a sigma70-conjugated chemical protease. Proc Natl Acad Sci USA. 1998;95(11):6021-6.

18. Yang $X, M a C$, Lewis P. A vector system that allows simple generation of mutant Escherichia coli RNA polymerase. Plasmid. 2014;75:37-41.

19. Zhang F, Qian X, Si H, Xu G, Han R, Ni Y. Significantly improved solvent tolerance of Escherichia coli by global transcription machinery engineering. Microb Cell Fact. 2015;14(1):175.

20. Hayashi S, Aono R, Hanai T, Mori H, Kobayashi T, Honda H. Analysis of organic solvent tolerance in Escherichia coli using gene expression profiles from DNA microarrays. J Biosci Bioeng. 2003;95(4):379-83.

21. Keeney D, Ruzin A, McAleese F, Murphy E, Bradford PA. MarA-mediated overexpression of the AcrAB efflux pump results in decreased susceptibility to tigecycline in Escherichia coli. J Antimicrob Chemother. 2008;61(1):46-53.

22. Doukyu N, Ishikawa K, Watanabe R, Ogino H. Improvement in organic solvent tolerance by double disruptions of proV and marR genes in Escherichia coli. J Appl Microbiol. 2012;112(3):464-74.

23. Rutherford BJ, Dahl RH, Price RE, Szmidt HL, Benke PI, Mukhopadhyay A, Keasling JD. Functional genomic study of exogenous n-butanol stress in Escherichia coli. Appl Environ Microbiol. 2010;76(6):1935-45.

24. Ni Y, Song L, Qian X, Sun Z. Proteomic analysis of Pseudomonas putida reveals an organic solvent tolerance-related gene $m m s B$. PLoS ONE. 2013;8(2):e55858

25. le Bui M, Lee JY, Geraldi A, Rahman Z, Lee JH, Kim SC. Improved n-butanol tolerance in Escherichia coli by controlling membrane related functions. J Biotechnol. 2015;204:33-44.

26. Dinh TN, Nagahisa K, Hirasawa T, Furusawa C, Shimizu H. Adaptation of Saccharomyces cerevisiae cells to high ethanol concentration and changes in fatty acid composition of membrane and cell size. PLoS ONE. 2008;3(7):e2623.

27. Kubota S, Takeo I, Kume K, Kanai M, Shitamukai A, Mizunuma M, Miyakawa T, Shimoi H, lefuji H, Hirata D. Effect of ethanol on cell growth of budding yeast: genes that are important for cell growth in the presence of ethanol. Biosci Biotechnol Biochem. 2004;68(4):968-72.

28. Neumann G, Veeranagouda Y, Karegoudar TB, Sahin O, Mausezahl I, Kabelitz N, Kappelmeyer U, Heipieper HJ. Cells of Pseudomonas putida and Enterobacter $s p$. adapt to toxic organic compounds by increasing their size. Extremophiles. 2005;9(2):163-8.

29. Aono R. Improvement of organic solvent tolerance level of Escherichia coli by overexpression of stress-responsive genes. Extremophiles. 1998;2(3):239-48.

30. Aono R, Kobayashi H, Joblin KN, Horikoshi K. Effects of organic solvents on growth of Escherichia coli K-12. Biosci Biotech Bioch. 1994;58(11):2009-14.

31. Yang J, Hong Y, Yuan C, Fu Z, Shi Y, Zhang M, Shen L, Han Y, Zhu C, Li H, Lu K, Liu J, Feng $X$, Lin J. Microarray analysis of gene expression profiles of Schistosoma japonicum derived from less-susceptible host water buffalo and susceptible host goat. PLoS ONE. 2013;8(8):e70367.

32. Fu F, Cheng VW, Wu Y, Tang Y, Weiner JH, Li L. Comparative proteomic and metabolomic analysis of Staphylococcus warneri SG1 cultured in the presence and absence of butanol. J Proteome Res. 2013;12(10):4478-89.

33. Fath MJ, Kolter R. ABC transporters: bacterial exporters. Microbiol Rev. 1993;57(4):995-1017.

34. Linton KJ, Higgins CF. The Escherichia coli ATP-binding cassette (ABC) proteins. Mol Microbiol. 1998;28(1):5-13.

35. SelfWT, Grunden AM, Hasona A, et al. Molybdate transport. Res Microbiol. 2001;152(3):311-21

36. Wissenbach U, Six S, Bongaerts J, Ternes D, Steinwachs S, Unden G. A third periplasmic transport system for L-arginine in Escherichia coli: molecular characterization of the artPIQMJ genes, arginine binding and transport. Mol Microbiol. 1995;17(4):675-86.

37. Chenault SS, Earhart CF. Organization of genes encoding membrane proteins of the Escherichia coli ferrienterobactin permease. Mol Microbiol. 1991;5(6):1405-13.

38. Horinouchi T, Tamaoka K, Furusawa C, Ono N, Suzuki S, Hirasawa T, Yomo T, Shimizu H. Transcriptome analysis of parallel-evolved Escherichia coli strains under ethanol stress. BMC Genom. 2010;11:579.
39. Mingardon F, Clement C, Hirano K, Nhan M, Luning EG, Chanal A, Mukhopadhyay A. Improving olefin tolerance and production in E. coli using native and evolved AcrB. Biotechnol Bioeng. 2015;112(5):879-88.

40. Watanabe R, Doukyu N. Improvement of organic solvent tolerance by disruption of the lon gene in Escherichia coli. J Biosci Bioeng. 2014;118(2):139-44.

41. Kuhn M, von Mering C, Campillos M, Jensen LJ, Bork P. STITCH: interaction networks of chemicals and proteins. Nucleic Acids Res. 2008;36:D684-8.

42. Archana KM, Ravi R, Anu-Appaiah KA. Correlation between ethanol stress and cellular fatty acid composition of alcohol producing non-Saccharomyces in comparison with Saccharomyces cerevisiae by multivariate techniques. J Food Sci Technol. 2015;52(10):6770-6.

43. Fozo EM, Quivey RG. Shifts in the membrane fatty acid profile of Streptococcus mutans enhance survival in acidic environments. Appl Environ Microbiol. 2004;70(2):929-36.

44. Nurlinawati, Vanoirbeek K, Aertsen A, Michiels CW. Role of 1-acyl-sn-glycerol-3-phosphate acyltransferase in psychrotrophy and stress tolerance of Serratia plymuthica RVH1. Res Microbiol. 2015;166(1):28-37.

45. Ramos JL, Duque E, Gallegos MT, Godoy P, Ramos-Gonzalez MI, Rojas A, Teran W, Segura A. Mechanisms of solvent tolerance in gram-negative bacteria. Annu Rev Microbiol. 2002;56:743-68.

46. Ramos JL, Duque E, Rodriguez-Herva JJ, Godoy P, Haidour A, Reyes F, Fernandez-Barrero A. Mechanisms for solvent tolerance in bacteria. J Biol Chem. 1997;272(7):3887-90.

47. You KM, Rosenfield CL, Knipple DC. Ethanol tolerance in the yeast Saccharomyces cerevisiae is dependent on cellular oleic acid content. Appl Environ Microbiol. 2003;69(3):1499-503.

48. Mannazzu I, Angelozzi D, Belviso S, Budroni M, Farris GA, Goffrini P, Lodi T, Marzona M, Bardi L. Behaviour of Saccharomyces cerevisiae wine strains during adaptation to unfavourable conditions of fermentation on synthetic medium: cell lipid composition, membrane integrity, viability and fermentative activity. Int J Food Microbiol. 2008;121(1):84-91.

49. Quivey RG Jr, Faustoferri R, Monahan K, Marquis R. Shifts in membrane fatty acid profiles associated with acid adaptation of Streptococcus mutans. FEMS Microbiol Lett. 2000;189(1):89-92.

50. Sikkema J, De Bont JA, Poolman B. Mechanisms of membrane toxicity of hydrocarbons. Microbiol Rev. 1995;59(2):201-22.

51. Hamadi F, Latrache $\mathrm{H}$. Comparison of contact angle measurement and microbial adhesion to solvents for assaying electron donor-electron acceptor (acid-base) properties of bacterial surface. Colloids Surf B Biointerfaces. 2008;65(1):134-9.

52. Aono R, Kobayashi H. Cell surface properties of organic solventtolerant mutants of Escherichia coli K-12. Appl Environ Microbiol. 1997;63(9):3637-42.

53. BellonFontaine MN, Rault J, VanOss CJ. Microbial adhesion to solvents: a novel method to determine the electron-donor/electron-acceptor or Lewis acid-base properties of microbial cells. Colloid Surface B. 1996;7(1-2):47-53.

54. Merritt $\mathrm{K}, \mathrm{An} \mathrm{YH}$. Factors influencing bacterial adhesion. Handbook of bacterial adhesion: principles, methods, and applications. Totowa: Humana Press; 2000. p. 53-72.

55. Guan L, Smirnova IN, Verner G, Nagamoni S, Kaback HR. Manipulating phospholipids for crystallization of a membrane transport protein. Proc Natl Acad Sci USA. 2006;103(6):1723-6.

56. de Planque MR, Killian JA. Protein-lipid interactions studied with designed transmembrane peptides: role of hydrophobic matching and interfacial anchoring. Mol Membr Biol. 2003;20(4):271-84.

57. Núñez MF, Kwon O, Wilson TH, Aguilar J, Baldoma L, Lin EC. Transport of L-Lactate, D-Lactate, and glycolate by the LIdP and GlcA membrane carriers of Escherichia coli. Biochem Biophys Res Commun. 2002;290(2):824-9.

58. Pellicer MT, Badia J, Aguilar J, Baldoma L. glc locus of Escherichia coli: characterization of genes encoding the subunits of glycolate oxidase and the g/c regulator protein. J Bacteriol. 1996;178(7):2051-9.

59. Clark DP, Cronan JE. Two-carbon compounds and fatty acids as carbon sources. EcoSal Plus. 2005. doi:10.1128/ecosalplus.3.4.4

60. Nemeria N, Binshtein E, Patel H, Balakrishnan A, Vered I, Shaanan B, Barak Z, Chipman D, Jordan F. Glyoxylate carboligase: a unique thiamin diphosphate-dependent enzyme that can cycle between the $4^{\prime}$-aminopyrimidinium and $1^{\prime}, 4^{\prime}$-iminopyrimidine tautomeric forms in the absence of the conserved glutamate. Biochemistry. 2012;51(40):7940-52. 
61. Breitling R, Armengaud P, Amtmann A, Herzyk P. Rank products: a simple, yet powerful, new method to detect differentially regulated genes in replicated microarray experiments. FEBS Lett. 2004;573(1-3):83-92.

62. Saeed Al, Sharov V, White J, Li J, Liang W, Bhagabati N, Braisted J, Klapa M, Currier T, Thiagarajan M, Sturn A, Snuffin M, Rezantsev A, Popov D, Ryltsov A, Kostukovich E, Borisovsky I, Liu Z, Vinsavich A, Trush V, Quackenbush J. TM4: a free, open-source system for microarray data management and analysis. Biotechniques. 2003;34(2):374-8.

63. Kanehisa M, Goto S, Furumichi M, Tanabe M, Hirakawa M. KEGG for representation and analysis of molecular networks involving diseases and drugs. Nucleic Acids Res. 2010;38:D355-60.
64. Bligh EG, Dyer WJ. A rapid method of total lipid extraction and purification. Can J Biochem Physiol. 1959;37(8):911-7.

65. Rosenberg M. Microbial adhesion to hydrocarbons: twenty-five years of doing MATH. FEMS Microbiol Lett. 2006;262(2):129-34.

66. Dembitsky VM, Řezanková H, Řezanka T, Hanuš LO. Variability of the fatty acids of the marine green algae belonging to the genus Codium Biochem Syst Ecol. 2003;31(10):1125-45.

67. Ni Y, Reye J, Chen RR. Ipp deletion as a permeabilization method. Biotechnol Bioeng. 2007;97(6):1347-56

\section{Submit your next manuscript to BioMed Central and we will help you at every step:}

- We accept pre-submission inquiries

- Our selector tool helps you to find the most relevant journal

- We provide round the clock customer support

- Convenient online submission

- Thorough peer review

- Inclusion in PubMed and all major indexing services

- Maximum visibility for your research

Submit your manuscript at www.biomedcentral.com/submit 